during 2000 had typing of monoclonal immunoglobulins or their fragments with the help of: I - serum agarosa gel and concentrated urine electrophoresis with subsequent densitometry of electrophoregraphs, 2 - immunofixation and immunoelectrophoresis with monospesific anti-serums ã, á, ì, å, ä, ê, ë.

Results IgMk-3, IgAk-2 monoclonal immunoglobulins were found in 5 pts $(25 \%)$ in blood serum, Bens-Johns protein (BJk) was found in urine of $3 \mathrm{pts}$ and IgMk in one patient. Thorough examination of pts with monoclonal secretion with carrying out of immunophenotyping of bioptates on lymphatic nodes and small salivary glands on lower lip enabled us to diagnose big cell lymphoma (2-ptorein BJk in the urine, IgMk in serum in 4 pts and plasmacytoma (IgGk) in one patient. It was not possible to confirm the presence of malignant lymphatic proliferation in this study in pts with IgAk (2), IgMk (1) monoclonal secretion in serum and vestige protein secretion BJk in the urine.

Conclusion Revealing of monoclonal immunoglobulins and light chains of immunoglobulins enables us to suggest the appearing of malignant lymphatic proliferation in SS pts and during further immunophenotyping of lymphatic nodes to diagnose the development of immunosecreting lymphomas in the half $(55 \%)$ of pts.

\section{FRI0228 ECHOCARDIOGRAPHIC FINDINGS IN PATIENTS WITH PRIMARY SJOGREN'S SYNDROME}

VA Vassiliou, I Moyssakis, KA Boki, MK Kyriakidis, HM Moutsopoulos. Department of Pathophysiology, National University of Athens School of Medicine, Athens, Greece

\subsection{6/annrheumdis-2001.321}

Background Cardiac involvement and clinically silent cardiac changes are reported rarely in patients with primary Sjogren's Syndrome (pSS) whereas: a. increased rate of pericarditis (usually silent with echocardiographic findings) and mitral valve regurgitation, b. myocardiac involvement (autoimmune - asymptomatic myocarditis), and c. left ventricular diastolic dysfunction have been presented in case reports and controlled studies.

Objectives The echocardiographic evaluation of the anatomic and functional heart disorders in patients with pSS (without risk factors for coronary heart disease or other symptoms of heart disease), the comparison of these findings with that of the control group, and the correlation with clinical and laboratory data (ANA, anti-Ro (SSA), anti-La (SSB), anti-CL, anti-b2GPI, RF).

Methods Pulsed, colour Doppler echocardiography was performed in seventy eight (78) patients (pts) with pSS (european criteria) (75 women and 3 men), mean age $51 \pm 11.6$ (years) and mean disease duration $7.7 \pm 4.26$ (years) and 80 healthy controls (78 women and 2 men) mean age $51 \pm 9.5$ (years). Left-ventricular (LV) dimensions and interventricular septum and posterior wall thickness at end-diastole were measured for the calculation of the fractional shortening (FS) and left ventricular mass with the Penn convention formula. Measurements of left ventricular mass were divided by body surface area to obtain left ventricular mass index (LVmass index). We also evaluated parameters of RV and LV diastolic function including early and late atrioventricular (AV) flow velocities ( $\mathrm{E}$ and $\mathrm{A}$ wave respectively), $\mathrm{E} / \mathrm{A}$ ratio, deceleration time (DT) and isovolumic relaxation time (IVRT). Pulmonary artery systolic pressure (PASP) was estimated by the peak regurgitation velocity from the tricuspid valve plus the estimated right atrial pressure, while valve lessions by continuous and colour Doppler.
Results Twenty-three (29.5\%) pts had mild mitral valve regurgitation versus 7 controls $(p<0.01), 6$ pts had mild tricuspid regurgitation $(\mathrm{p}<0.05)$ and $14(18 \%)$ pts had mild aortic valve regurgitation. Pericardial effusion was found in 3 pts whereas fourteen $(18 \%)$ pts had pulmonary hypertension (PASP >35 $\mathrm{mmHg})(\mathrm{p}<0.001)$. Mitral valve regurgitation was significantly associated with the presence of the anti-La antibodies $(\mathrm{p}<0.05)$ and pulmonary hypertension with lung disease (carbon monoxide diffusing capacity ${ }^{-2}$ vs $\left.84.71 \pm 15.36 \mathrm{gm}^{-2}, \mathrm{p}<0.001\right)$ and was correlated with the presence of purpura $(P=0.02)$, lung disease $(\mathrm{p}<0.001)$ and the presence of rheumatoid factor $(\mathrm{P}=$ 0.02).

Conclusion Patients with pSS and no clinically apparent heart disease had, more often than healthy controls, mild mitral and tricuspid valve regurgitation, pulmonary hypertension, and had increased left ventricular mass index. The LV mass index is correlated with purpura, lung disease and the presence of rheumatoid factor.

\section{FRI0229 HLA ANTIGENS' FREQUENCIES IN SPANISH PATIENTS WITH PRIMARY SJÖGREN SYNDROME}

C Fernández-Carballido, JJ Alegre-Sancho, JA Román-Ivorra, S Fernández, L Abad, N Puig. Sección de Reumatología, Hospital Universitario Dr. Peset, Valencia, Spain

\subsection{6/annrheumdis-2001.322}

Background There are few data about HLA antigens' frequencies in Spanish patients with Primary Sjögren Syndrome (PSS).

Objectives To evaluate HLA antigens' prevalence in patients with PSS and compare these frequencies with a control population.

Methods 113 patients with PSS from a Mediterranean city (Valencia, Spain) were consecutively selected. All patients fulfilled 4 or more EEC criteria; 82 fulfilled modified-EEC criteria. HLA serologic typing was carried out and the frequencies obtained in PSS patients were compared with the control population's frequencies (236 healthy blood donnors from the same city).

Results The antigens' prevalences of PSS patients significatively different from the control group were:

\begin{tabular}{|c|c|c|c|c|c|c|}
\hline & B21 & DR1 & DR2 & DR3 & DR4 & DR7 \\
\hline $\begin{array}{l}\text { All } \\
\text { patients ( } n \\
=113 \text { ) }\end{array}$ & $\begin{array}{l}\mathrm{OR}=0.36 \\
(0.18- \\
0.74) ; \mathrm{P}= \\
0.002\end{array}$ & $\begin{array}{l}\mathrm{OR}=0,4 \\
(0.23- \\
0.94) ; p= \\
0,022\end{array}$ & $\begin{array}{l}\mathrm{OR}=1.93 \\
(1.08- \\
3.46) ; \mathrm{p}= \\
0.017\end{array}$ & $\begin{array}{l}\mathrm{OR}=1.98 \\
(1.05- \\
3.02) ; p= \\
0.03\end{array}$ & $\begin{array}{l}\mathrm{OR}=2.09 \\
(1.16- \\
3.74) ; p= \\
0.007\end{array}$ & $\begin{array}{l}\mathrm{OR}=0.51 \\
(0.28- \\
0.90) ; p= \\
0.013\end{array}$ \\
\hline $\begin{array}{l}\text { Modified- } \\
\text { EEC } \\
\text { criteria } \\
\text { only ( } n= \\
82 \text { ) }\end{array}$ & $\begin{array}{l}\text { No } \\
\text { significance }\end{array}$ & $\begin{array}{l}\text { No } \\
\text { significance }\end{array}$ & $\begin{array}{l}\mathrm{OR}=2.13 \\
(1.17- \\
3.89) ; \mathrm{p}= \\
0.014\end{array}$ & $\begin{array}{l}\mathrm{OR}=2.02 \\
(1.16- \\
3.50) ; p= \\
0.018\end{array}$ & $\begin{array}{l}\mathrm{OR}=2.34 \\
(1.29- \\
4.27) ; \mathrm{p}= \\
0.008\end{array}$ & $\begin{array}{l}\mathrm{OR}=0.47 \\
(0.25- \\
0.88) ; p= \\
0.019\end{array}$ \\
\hline
\end{tabular}

Conclusion Some HLA antigens in our PSS patients are different from those described in other Mediterranean areas. In our population HLA DR2, DR3 and DR4 are associated with PSS; without differences in DR5 frequencies (Greek population). Moreover, HLA DR7 acts as a protective factor for this disease. 